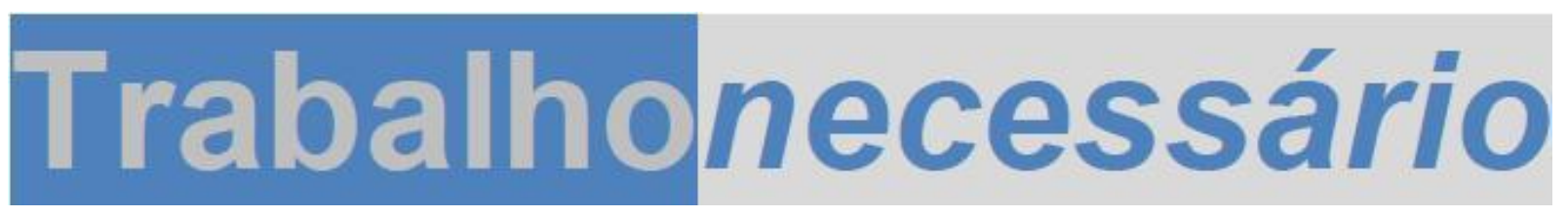

Issn: 1808 - 799X

ano 12 , no $18-2014$

\title{
E. P. THOMPSON, A HISTORIOGRAFIA BRASILEIRA E A VALORIZAÇÃO DAS EXPERIÊNCIAS DOS TRABALHADORES
}

\author{
Marcelo Mac Cord ${ }^{1}$
}

\section{Resumo}

O artigo aponta para a importância da experiência nas obras de E. P. Thompson. Para o marxista inglês, as lutas e os interesses em comum dos trabalhadores de seu país foram fatores fundamentais para a construção da classe operária nacional. Nos últimos 30 anos, no Brasil, essa perspectiva processual da formação da classe operária foi crucial para a renovação de nossa história social do trabalho e da cultura. Sob o olhar thompsoniano, sempre atento às fontes, foram revelados novos aspectos da vida dos trabalhadores brasileiros que viveram no passado, assim como foram reinterpretados os já conhecidos. O texto também explora um importante desdobramento político e científico da construção de uma história brasileira vista de baixo. Os introdutores de E. P. Thompson em nosso país ainda seguem formando quadros de historiadores sociais vindos de baixo. Por fim, o artigo demonstra como o ativismo social do marxista inglês também é inspirador para projetos extensionistas preocupados com a educação de trabalhadores precarizados.

Palavras-chave: experiência; trabalhadores; história social.

\footnotetext{
${ }^{1}$ Professor Adjunto de História da Educação da Faculdade de Educação da Universidade Federal Fluminense/UFF. Doutor em História Social do Trabalho pela Universidade Estadual de Campinas/UNICAMP. mmcord@uol.com.br
} 


\title{
Trabalhonecessário
}

Issn: 1808 - 799X

ano 12, no $18-2014$

\begin{abstract}
This paper points out the importance of the experience in the works of $E$. P. Thompson. For the English Marxist, the common fights and interests of the workers of his country were essential factors for building the national workman class. In the last 30 years, in Brazil, this procedural perspective of workers class formation was crucial to the renewal of our social history of labor and culture. Under the Thompsian view, always watchful to the sources, new aspects were revealed of the live of the Brazilian workers who lived in the past, just as those already known were re-interpreted. The text also explores an important political and scientific unfolding from building a Brazilian history seen from below. The introducers of E. P. Thompson in our country still go on forming pictures of social historians coming from below. Lastly, this paper shows how the social activism of the English Marxist is also inspiring for extensionist projects concerned with the education of workers in precarious conditions.
\end{abstract}

Keywords: experience; works; social history

O texto que apresento aos leitores é fruto das reflexões que desenvolvi no seminário "Trabalho, história e experiência de classe: Thompson 50 anos depois", que foi organizado pelo Núcleo de Estudos, Documentação e Dados sobre Trabalho e Educação/Neddate/UFF. Ao compor a mesa "Movimentos sociais, educação e experiência de classe" na qualidade de historiador social, fui compelido, por dever de ofício, a pensar na importância dos estudos do marxista inglês para o desenvolvimento da especialidade em nosso país. Contudo, minha exposição foi além do problema historiográfico propriamente dito. Sublinhei a relevância e o significado das análises de $\mathrm{E}$. P. Thompson para a valorização de experiências formadoras da classe trabalhadora brasileira em espaços alternativos aos partidos e aos sindicatos - sem desconsiderá-los, obviamente. Junto disso, discuti como podemos nos apropriar da atuação daquele intelectual enquanto ativista preocupado com a educação fora dos muros universitários, pois era pessoa absolutamente comprometida com a chamada "gente comum".

TrabalhoNecessário - www.uff.br/trabalhonecessario; Ano 12, № 18/2014. 


\section{Trabalhonecessário}

Issn: 1808 - $799 \mathrm{X}$

ano 12, no $18-2014$

No transcorrer de minha comunicação na mesa "Movimentos sociais, educação e experiência de classe", e dos debates por ela suscitados, realizei cruzamentos entre as questões thompsonianas, minha trajetória acadêmica (pesquisa, docência e extensão) e minhas experiências pessoais. A estratégia teve por objetivo ilustrar meus argumentos sobre a importância das vivências e das expectativas dos trabalhadores - como objeto de pesquisa, como justificativa para projetos político-pedagógicos e como diferencial epistemológico dos historiadores vindos de baixo e que produzem histórias vistas de baixo. ${ }^{2}$ Peço desculpas aos leitores pelos momentos autocentrados desse texto, mas, como comentei pouco acima, eles foram acionados muito mais como um caso comparativo. Caso os retirasse desse artigo, teria que escrever algo muito distante de minha fala original. Por tudo isso, preferi respeitar as peculiaridades de minha apresentação no seminário "Trabalho, história e experiência de classe: Thompson 50 anos depois".

Nesse artigo, apenas aprofundei minha fala original quando discorri sobre o projeto de extensão "Limpeza Total: EJA, UFF e Trabalhadores Terceirizados". Na ocasião do seminário "Trabalho, história e experiência de classe: Thompson 50 anos depois", que ocorreu em setembro do ano passado, aquela ação políticopedagógica ainda estava em processo coletivo de elaboração, como havia relatado aos ouvintes. Nos debates abertos que promovemos naquele período, que foram convocados por meio de panfletagens, foram protagonistas alguns faxineiros do campus do Gragoatá e algumas graduandas da Faculdade de Educação da UFF. Passados seis meses entre minha fala na mesa "Movimentos sociais, educação e experiência de classe" e a escrita desse texto, o projeto

\footnotetext{
${ }^{2}$ Mais conhecida na Inglaterra dos anos 1980 como history from below, a história vista de baixo é uma corrente historiográfica preocupada com a análise dos sujeitos históricos que foram negligenciados pelas formas mais tradicionais de escrita sobre o passado. As formas de vida, de trabalho e de cultura dos mais pobres são seu principal objeto de estudo. SHARPE, Jim Sharpe.

"A história vista de baixo". In: Peter Burke (org.). A Escrita da história: novas perspectivas. São Paulo: Editora da UNESP, 1992, p. 39-62.
}

TrabalhoNecessário - www.uff.br/trabalhonecessario; Ano 12, №18/2014. 


\section{Trabalhonecessário}

Issn: 1808 - 799X

ano 12, no $18-2014$

extensionista ganhou forma, espaço, fôlego e diretriz. É bastante significativo registrarmos os mais recentes passos dessa iniciativa, que cruza educação das classes subalternas e identidade de classe, assuntos candentes na trajetória intelectual e militante de E. P. Thompson.

\section{O diálogo da historiografia brasileira com as obras de E. P. Thompson}

Desde meados dos anos 1980, a obra de E. P. Thompson conquistou significativa ressonância na historiografia brasileira. Nos debates sobre 0 centenário da abolição do trabalho escravo, em 1988, jovens e então promissores historiadores publicaram importantes textos baseados em substancial pesquisa empírica. Eles relativizaram alguns pressupostos defendidos pela Escola Sociológica Paulista, que, desde os anos 1960, afirmavam a anomia do escravo e a incapacidade do negro de se integrar à sociedade de classes. Por meio de novas fontes, como, por exemplo, processos criminais e cíveis, aqueles profissionais perceberam que os cativos tinham expectativas próprias, sendo que todas elas estavam solidamente ancoradas em suas experiências e visões de mundo. Marcada por costumes comuns e noções de direito vindas de baixo, essa economia moral fazia dos africanos escravizados senhores de suas vidas, sujeitos de suas histórias. Como podemos facilmente perceber, essas interpretações autonomistas dialogavam com as obras do marxista inglês. ${ }^{3}$

\footnotetext{
${ }^{3}$ LARA, Silvia H. "Blowin'in the wind: E. P. Thompson e a experiência negra no Brasil". Projeto História, (1995), n. 12, 1995, p. 43-56. Somente para exemplificar, dois ótimos exemplos de teses que muito bem representam esse movimento: CHALHOUB, Sidney. "Visões da liberdade: uma história das últimas décadas da escravidão na Corte" (Tese de Doutorado, UNICAMP, 1989). A primeira edição do livro homônimo foi publicada pela Companhia das Letras, em 1990. LARA, Silvia $\mathrm{H}$. "Campos da violência: estudo sobre a relação senhor-escravo na capitania do Rio de Janeiro, 1750-1808" (Tese de Doutorado, USP, 1986). A primeira edição do livro homônimo foi publicada pela Paz e Terra, em 1988. A história da escravidão de matriz thompsoniana foi criticada por GORENDER, Jacob. A escravidão reabilitada. São Paulo: Editora Ática, 1990.
}

TrabalhoNecessário - www.uff.br/trabalhonecessario; Ano 12, № 18/2014. 


\section{Trabalhonecessário}

Issn: $1808-799 X$

ano 12, no $18-2014$

Da mesma forma, nas últimas três décadas, os trabalhos de $E$. $P$. Thompson também foram muito importantes para a renovação dos estudos sobre a formação da classe operária brasileira. Estudos de cunho sociologizante, produzidos fundamentalmente nas décadas de 1960 e 1970, entenderam que a classe operária nacional somente encontrou condições para se formar com 0 advento da nossa modernização capitalista. A chamada "Era Vargas" seria o momento de "nascimento" do grupo, que foi viabilizado pelo incremento da industrialização, pelo fomento da urbanização e pela formação de sindicatos mais bem representativos. Nesse processo de emergência da classe operária brasileira, devemos recordar também o surgimento do PCB, ocorrido no ano de 1922. Na tradicional perspectiva marxista, esse partido conquistou o status de marco divisório na organização nacional da luta de classes. Historiadores sociais brasileiros, thompsonianos, sem desconsiderar tais conjunturas, observaram, nas fontes, que é possível relativizar as referidas fronteiras temporais. ${ }^{4}$

Tal renovação da historiografia brasileira não brotou do nada, como que por encanto. O país vivia um momento muito especial de sua história intelectual e política quando os historiadores da escravidão e do movimento operário travaram diálogos com as obras de E. P. Thompson. Dávamos consistentes passos no processo de redemocratização, os sindicatos mais combativos se reorganizavam, os programas de pós-graduação em história conquistavam contornos mais profissionais, um modelo mais ortodoxo de marxismo era questionado pelas bases e os movimentos sociais reemergiam nas ruas. As conjunturas impunham novas agendas aos intelectuais de esquerda. Neste movimento, as classes subalternas fizeram pressão por legitimidade social, direito à memória e ampla participação política. No bojo desse processo, categorias thompsonianas como

\footnotetext{
${ }^{4}$ BATALHA, Claudio H. M. "A historiografia da classe operária no Brasil: trajetórias e tendências". In: Marcos C. de Freitas (org.). Historiografia brasileira em perspectiva. São Paulo: Contexto, 2003, p. 145-58. Idem, "Identidade da classe operária no Brasil (1880-1920): atipicidade ou legitimidade?". Revista Brasileira de História, (set. 1991/ago. 1992), v. 12, n. 23/24, p. 111-24.
}

TrabalhoNecessário - www.uff.br/trabalhonecessario; Ano 12, № 18/2014. 


\section{Trabalhonecessário}

Issn: 1808 - 799X

ano 12, no $18-2014$

"agência", "experiência" e "costumes comuns" permitiram que ouvíssemos as vozes dos excluídos que viveram no passado por meio de suas próprias vivências e expectativas - e não por aquelas do observador. ${ }^{5}$

$\mathrm{Na}$ bem sucedida trajetória dessa historiografia brasileira da escravidão e do movimento operário, de matriz thompsoniana, seus representantes também procuram relativizar outras perspectivas hegemônicas no estudo do mundo do trabalho. Desde a elaboração dos primeiros textos da renovadora corrente historiográfica, em meados dos anos 1980, um de seus mais importantes combates se voltou contra a tese da "transição" do trabalho escravo para o trabalho livre, como se existisse um movimento teleológico, evolutivo, entre ambas as formas de emprego da mão de obra. ${ }^{6} \mathrm{O}$ velho paradigma ainda não está totalmente superado, mas muitas dissertações e teses conseguiram relativizar algumas das dicotomias que criaram um abissal abismo entre senzalas e fábricas. ${ }^{7}$ Atualmente, maior atenção tem sido conferida aos processos de reescravização durante o Império do Brasil e de precarização da liberdade antes e pós-Abolição, o que permite que abalemos ainda mais as combalidas estruturas do "muro de Berlim historiográfico" que separa trabalho escravo e trabalho livre. ${ }^{8}$

\footnotetext{
${ }^{5}$ CHALHOUB, Sidney; FONTES, Paulo. "História Social do Trabalho, História Pública". Perseu: história, memória e política, (2009), n. 4, ano 3, p. 219-28.

${ }^{6}$ LARA, Silvia H. "Escravidão, cidadania e história do trabalho no Brasil". Projeto História, (1998), n. 16, p. $25-38$.

${ }^{7}$ NEGRO, Antonio L.; GOMES, Flávio dos S. "Além de senzalas e fábricas: uma história social do trabalho". Tempo Social: revista de sociologia da USP, (2006), v. 18, n. 1, p. 217-40.

8 CHALHOUB, Sidney; TEIXEIRA, Fernando. "Sujeitos no imaginário acadêmico: escravos e trabalhadores na historiografia brasileira desde os anos 1980". Cadernos AEL, (2009), v. 14, p. 11-50.
}

TrabalhoNecessário - www.uff.br/trabalhonecessario; Ano 12, № 18/2014. 


\section{Trabalhonecessário}

Issn: 1808 - 799X

ano 12 , no $18-2014$

\section{História vista de baixo e a formação de historiadores vindos de baixo.}

O quadro introdutório que apresentei ao leitor não dá conta das complexidades que envolvem a historiografia brasileira inspirada nas obras de $\mathrm{E}$. P. Thompson. Entretanto, ele permite que possamos afirmar algo muito importante: nos últimos trinta anos, os historiadores sociais da escravidão e do movimento operário se preocuparam muito mais em dialogar com as fontes e compreender as mundividências dos homens e das mulheres do passado do que enquadrá-las em modelos apriorísticos, explicativos. Sem abrir mão de categorias fundamentais como "classe" ou "luta de classes", esses intelectuais entenderam que era preciso compreendê-las como algo processual, fruto das tensões dialéticas entre as condições materiais de existência e a agência dos homens e das mulheres que viveram em outros tempos. ${ }^{9}$ A partir de um novo olhar fundado na experiência dos sujeitos históricos, baseado em profunda pesquisa empírica, eles enfraqueceram concepções mais ortodoxas e estruturalizantes, tão caras aos "velhos" marxistas que tendiam a engessar a história das classes trabalhadoras.

No Brasil, a construção de uma história vista de baixo pela primeira geração de intelectuais thompsonianos foi acompanhada de profunda sensibilidade social. Nos programas de pós-graduação em que estavam instalados, notamos que eles criaram políticas educacionais e científicas que buscaram promover a formação de estudantes oriundos das classes subalternas, fossem eles negros ou brancos pobres. O resultado disso é que, desde o início da década de 1990, se avolumam os exemplares de dissertações e de teses que discutem as experiências históricas dos excluídos por meio da pena de

\footnotetext{
${ }^{9}$ Para saber mais sobre o entendimento da "classe" como processo, consultar THOMPSON, E. P. $A$ formação da classe operária inglesa: a árvore da liberdade, v. 1, $3^{\text {a }}$ ed. Rio de Janeiro: Paz e Terra, 1997.
}

TrabalhoNecessário - www.uff.br/trabalhonecessario; Ano 12, № 18/2014. 


\section{Trabalhonecessário}

Issn: 1808 - 799X

ano 12 , no $18-2014$

pesquisadores vindos de baixo da pirâmide social. ${ }^{10}$ Sem sombra de dúvidas, esses novos olhares permitem que ampliemos o espectro de objetos estudados $e$ diversifiquemos suas interpretações. Apesar disso, não estou afirmando que somente esses últimos historiadores possam fazer bons trabalhos sobre as classes subalternas, mas é inegável a importância de suas experiências classistas e/ou raciais como fator de sensibilização interpretativa.

A história vista de baixo que vem sendo escrita por historiadores vindos de baixo é mais uma prova contundente da necessidade de políticas afirmativas nas universidades públicas brasileiras. Incluir e diversificar o perfil social dos estudantes de graduação e de pós-graduação abre possibilidades de renovação epistemológica em vários ramos do saber científico - e não somente no campo da historiografia, como comentei até aqui. A presença e a visibilidade das classes subalternas no ensino superior também abrem possibilidades de renovação política nos campus. Algumas entidades de esquerda, mais próximas das organizações estudantis, precisarão ouvir novas bases e incluir outras lutas e demandas sociais em suas agendas. Ainda temos poucos negros, favelados e trabalhadores nos bancos universitários. Suas vozes têm sido relativamente ouvidas, mas muitas vezes são filtradas por discursos hegemônicos, como os que são produzidos por militantes brancos de "classe média", que muito falam sobre os excluídos sem considerar suas expectativas mais concretas. ${ }^{11}$

\footnotetext{
10 Nesse espaço, não há condições para arrolarmos muitas obras. Cito apenas duas muito emblemáticas, escritas, respectivamente, por historiadores negro e branco oriundos das classes trabalhadoras: GOMES, Flávio dos S. "Histórias de quilombolas: mocambos e comunidades de senzalas - Rio de Janeiro, século XIX" (Dissertação de Mestrado, UNICAMP, 1993). O livro homônimo foi publicado pelo Arquivo Nacional, em 1993. FORTES, Alexandre. "Nós do Quarto Distrito: a classe trabalhadora Porto-alegrense e a Era Vargas" (Tese de Doutorado, UNICAMP, 2001). O livro homônimo foi publicado pela Editora Garamond, em 2004.

${ }^{11}$ A presença dos negros nas universidades, por exemplo, abriu novos debates sobre o que podemos considerar luta por direitos. Um grupo de estudantes negros oriundos de pré-vestibulares sociais chegou ao ensino superior e redimensionou o significado de suas vidas cotidianas por meio da afirmação de sua afrocidadania. Para saber mais, consultar GUIMARÃES, Reinaldo da S.
}

TrabalhoNecessário - www.uff.br/trabalhonecessario; Ano 12, № 18/2014. 


\section{Trabalhonecessário}

Issn: 1808 - 799X

ano 12, no $18-2014$

Tais questões políticas e científicas são extremamente importantes para os estudantes universitários oriundos das classes subalternas. Nesse sentido, já que a categoria "experiência" é uma das importantes para E. P. Thompson, peço licença ao leitor para contar a minha em espaços acadêmicos, pois faço parte da geração de historiadores thompsonianos que vieram de baixo e fazem história vista de baixo. No início dos anos 1990, quando entrei na universidade pública como graduando em história, ficava um pouco incomodado ao ouvir algumas assertivas sobre conceitos como "popular" e "trabalhador". Nos debates de então, eles ora apareciam ensimesmados (nos estudos culturalistas), ora profundamente marcados por idealizações - como na ortodoxia marxista. Aqueles que, como eu, não se enquadravam nos perfis esboçados por tais correntes, eram (des)classificados em uma espécie de "não lugar" epistemológico. Nós éramos invisíveis, os trabalhadores precarizados sem representação partidário-sindical e que não frequentavam "típicos" lugares da "cultura popular".

O encontro com as obras de E. P. Thompson permitiu que eu legitimasse minhas experiências no seio das classes subalternas, apesar de elas serem, à época, consideravelmente desprezadas como objeto de estudo histórico na universidade pública em que me graduei - IFCS/UFRJ. Por meio das problematizações contidas nas obras do marxista inglês, relativizei, por exemplo, a perspectiva mecanicista de que existe "classe em si" e "classe para si". Maniqueísta, tal princípio nos faz crer que somente nos sindicatos e nos atuais partidos operários as classes subalternas atingem a "consciência" de que haviam sido "alienadas" de sua "real identidade" e da "realidade" que a cerca. Nesse ponto de vista, nas favelas, nas igrejas, no subemprego sem direitos formais e na luta por direitos costumeiros, os de baixo estariam "inconscientes" de sua submissão a um "sistema" montado pelos grupos dominantes. Entendo que seja

Afrocidanização: ações afirmativas e trajetórias de vida no Rio de Janeiro. Rio de Janeiro/São Paulo, Editora da PUC-RJ: Selo Negro Edições, 2013.

TrabalhoNecessário - www.uff.br/trabalhonecessario; Ano 12, № 18/2014. 


\section{Trabalhonecessário}

Issn: 1808 - 799X

ano 12 , no $18-2014$

preciso matizar afirmativas desse tipo. Os condicionamentos ideológicos são um dos fatores dessa complicada equação, mas não é ela própria.

\section{Artesãos e operários organizados, escolarizados e descendentes de africanos no Recife oitocentista.}

Ao final de minha graduação no curso de história, entendi que precisava encontrar um grupo de pesquisa que me permitisse estudar o passado das classes subalternas por meio de minhas próprias referências, inquietações e experiências - pessoais e acadêmicas. No Centro de Pesquisa em História Social da Cultura/CECULT/UNICAMP, importante referência internacional nos estudos de matriz thompsoniana, desenvolvi minhas investigações de pós-graduação entre finais da década de 1990 e inícios dos anos de 2010. Nesse artigo, contudo, irei me ater somente aos resultados de minhas pesquisas de doutorado e pósdoutorado, realizadas entre 2004 e $2012 .^{12}$ Junto deles, tecerei alguns comentários sobre os resultados parciais de meu atual projeto de pesquisa, que executo, desde 2013, enquanto professor da Faculdade de Educação da Universidade Federal Fluminense. ${ }^{13}$ Os três exercícios investigativos vão ao

\footnotetext{
12 MAC CORD, Marcelo. "Andaimes, casacas, tijolos e livros: uma associação de artífices no Recife, 1836-1880" (Tese de Doutorado, UNICAMP, 2009). Após conquistar algumas importantes premiações, minha tese de doutorado foi publicada pela Editora da UNICAMP, no ano de 2012, sob o título de Artífices da cidadania: mutualismo, educação e trabalho no Recife oitocentista. No pós-doutorado, desenvolvi, entre os anos de 2010 e 2012, o projeto de pesquisa "A União Artística: trabalhadores especializados, identidade de classe e reivindicação de direitos. Recife, últimas décadas do oitocentos". O resultado da investigação está no texto "Imperial Sociedade dos Artistas Mecânicos e Liberais: mutualismo, cidadania e a reforma eleitoral de 1881 no Recife", que será brevemente publicado pela Editora da UNICAMP em uma coletânea organizada por mim e Claudio Batalha. A mesma comporá a Coleção Várias Histórias, organizada pelo CECULT/UNICAMP.

${ }^{13}$ O título do projeto de pesquisa é "Operários e artífices organizados e sua luta pela jornada de 8 horas. Recife, 1890-1891" e recebe financiamento da CAPES. A bolsa foi um prêmio pela conquista do Prêmio CAPES de melhor de tese de história do ano de 2010.
}

TrabalhoNecessário - www.uff.br/trabalhonecessario; Ano 12, № 18/2014. 


\section{Trabalhonecessário}

Issn: 1808 - 799X

ano 12, no $18-2014$

encontro dos objetivos propostos pela mesa "Movimentos sociais, educação e experiência de classe".

As pesquisas que realizo têm como foco a cidade do Recife, capital de Pernambuco, entre os anos de 1836 e 1891. Os principais sujeitos de minhas investigações são os artífices e os operários especializados que eram descendentes de africanos, estavam organizados em entidades próprias e demandavam escolarização formal. Mesmo antes do dia 13 de maio de 1888, quando foi abolida a escravidão em nosso país, todos esses trabalhadores que analiso eram homem livres. As suas lutas por estudo regular tinham por objetivo combater dois estigmas: da escravidão e do defeito mecânico. Em sua ótica, na medida em que se instruíssem, conseguiriam provar aos pernambucanos que eles trabalhavam com perícia e inteligência, além de demonstrar que estavam aptos a participar do concerto da "civilização" e do "progresso" como homens relativamente letrados. No pós-abolição e nos primeiros anos da República, tais agentes lutaram para que suas liberdades não fossem precarizadas e sua força de trabalho não sofresse processos de proletarização.

Do ponto de vista historiográfico, essas pesquisas relativizam o antigo paradigma da "transição" do trabalho escravo para o trabalho livre. Em primeiro lugar, comprovo empiricamente que, durante o escravismo, existiu um processo de construção de identidade de classe no país, mesmo que, verticalizado, somente incluísse os artífices e os operários livres e qualificados. As irmandades embandeiradas e as sociedades mutualistas foram organizações que aglutinaram esses trabalhadores e fortaleceram identidades sociais e lutas no mundo do trabalho. Por causa disso, questiono veementemente a pretensa anomia dos sujeitos que investiguei. Por sua vez, no pós-abolição e nos primeiros anos da República, os mesmo atores sociais, organizados em ligas operárias, acreditaram que poderiam qualificar ainda mais sua cidadania por meio de direitos trabalhistas e educacionais que impedissem a precarização de suas liberdades. A

TrabalhoNecessário - www.uff.br/trabalhonecessario; Ano 12, № 18/2014. 


\section{Trabalhonecessário}

Issn: 1808 - 799X

ano 12, no $18-2014$

proletarização do mercado de trabalho e o racismo científico pressionavam a todo o momento as históricas conquistas do que era conhecido como classe artística.

No livro Artífices da cidadania, resultado de minha tese de doutorado, observei como um grupo de mestres de obras pretos e pardos (forma como se definiam), composto por pernambucanos livres, organizou uma sociedade de auxílio mutuo no final da década de 1830. A maior parte deles era membro da Irmandade de São José do Ribamar, entidade leiga que congregava pedreiros, carpinteiros, tanoeiros e calafates. Até a outorga da Constituição de 1824, essa organização tinha o privilégio de monopolizar o ensino, a prática e os mercados de seus ofícios. Fundada em 1841, a Sociedade das Artes Mecânicas tinha dois objetivos centrais: promover apoio financeiro e oferecer aulas noturnas para seus sócios. Como afirmei mais acima, essa estratégia pretendia evidenciar que eles eram trabalhadores disciplinados e preocupados com sua qualificação, o que combatia frontalmente os estigmas da escravidão (que imputava inépcia aos africanos e seus descendentes) e do defeito mecânico - que julgava o trabalho manual como uma atividade sem inteligência.

A Sociedade das Artes Mecânicas foi criada tendo como base alguns princípios muito valorizados em oficinas, canteiros de obras e tendas abertas: a perícia, o orgulho pelo trabalho bem feito, o tirocínio artesanal e a respeitabilidade no mundo do trabalho. Como podemos inferir, o grupo de auxílio mútuo foi fruto de costumes compartilhados por artífices que eram descendentes de africanos e oriundos de baixo da pirâmide social. Entre os anos 1840 e 1880, o projeto daqueles trabalhadores foi tão bem sucedido que alguns deles abocanharam serviços em canteiros de obras públicas e particulares, conquistaram vagas de professor público, participaram da organização de exposições provinciais (as chamadas "festas do progresso"), controlaram o Gabinete Artístico (órgão ligado ao governo local para o aperfeiçoamento das artes mecânicas), articularam a montagem da União Artística (entidade de classe que queria promovê-los à

TrabalhoNecessário - www.uff.br/trabalhonecessario; Ano 12, № 18/2014. 


\section{Trabalhonecessário}

Issn: 1808 - 799X

ano $12, \mathrm{n}$ - $18-2014$

condição de parlamentares) e fundaram o Liceu de Artes e Ofícios do Recife ocupando cargos de direção e docência. ${ }^{14}$

No pós-doutorado investiguei a União Artística, projeto político strictu sensu dos trabalhadores especializados nos anos 1870. Uma de suas propostas era eleger deputados oriundos de seus quadros. Naquela década, a "boa sociedade" estava incomodada com o crescimento do número de pessoas aptas a comparecer às urnas. Entre essas últimas, ex-escravos e seus descendentes, pois, no período em quadro, o escravismo seguia sofrendo importantes revezes. Em 1881, a reforma eleitoral resolveu o "problema" da ampliação da cidadania política desqualificando os analfabetos e exigindo mais rigor na comprovação da renda. Tal medida excluiu 90\% dos que podiam votar. Em sua maioria, essas pessoas viviam do suor do próprio rosto, era desescolarizada, tinha a pele escura e encontrava dificuldade para comprovar remuneração. A União Artística não saiu do papel, mas seus idealizadores, escolarizados e capazes de comprovar renda, mantiveram o direito de votar e conquistaram vantagens por causa disso. Contudo, não tiveram força política para ocupar cadeiras legislativas. ${ }^{15}$

A luta política strictu sensu travada pelos artífices e operários qualificados se acirrou nos primeiros anos da República, como posso observar em meu atual projeto de pesquisa, em fase de execução. Contrariando a tese de que a

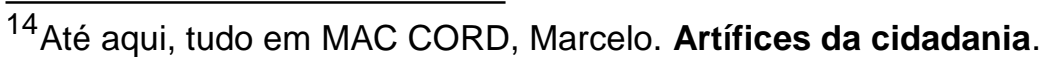

${ }^{15}$ Até aqui, tudo em MAC CORD, Marcelo. "Imperial Sociedade dos Artistas Mecânicos e Liberais: mutualismo, cidadania e a reforma eleitoral de 1881 no Recife". No prelo. Entre os anos de $1824 \mathrm{e}$ 1881, as eleições imperiais ocorriam em dois turnos e eram censitárias. No primeiro turno, indireto, os votantes (por exemplo, ex-escravos nascidos no país e trabalhadores que comprovassem renda anual de $100 \$ 000$ rs) escolhiam os eleitores - homens nascidos livres com renda anual de $200 \$ 000$ rs. No segundo turno, os eleitores escolhiam deputados e senadores. Vale destacar que ambos os valores exigidos para qualificação foram relativamente baixos durante toda a vigência da monarquia. A eleição direta ocorria, por exemplo, na escolha de vereadores e juízes de paz. A reforma eleitoral de 1881 determinou que todas as eleições fossem diretas, mas somente seriam qualificados os brasileiros alfabetizados que efetivamente comprovassem seus rendimentos. Como afirmei, a medida draconiana eliminou aproximadamente $90 \%$ das pessoas que até então iam às urnas. Para saber mais, ver CARVALHO, José M. de. Cidadania no Brasil: o longo caminho, 13를 ed. Rio de Janeiro: Civilização Brasileira, 2010.
} 


\section{Trabalhonecessário}

Issn: 1808 - 799X

ano 12, no $18-2014$

população brasileira, de forma geral, assistiu "bestializada" aos acontecimentos do dia 15 de novembro de 1889, as fontes pernambucanas permitem outras percepções. No Recife, no transcorrer de 1891, greves foram deflagradas por várias categorias. Dentre as demandas, melhorias nos salários e nas condições de trabalho. $\mathrm{Na}$ articulação de algumas delas, encontramos entidades de classe como a Liga Operária de Pernambuco e o Gabinete Artístico-Operário de Pernambuco. As pressões se adensaram de tal forma que exigiram prontas respostas governamentais. A que mais me interessa foi o debate sobre o projeto de lei estadual que pretendia diminuir a jornada de trabalho para 8 horas, para que operários e artífices tivessem tempo livre para estudar. Aprovada pelos deputados estaduais, a mesma não passou pelo senado estadual. ${ }^{16}$

\section{Estudar os trabalhadores do passado e estudar com os trabalhadores do presente.}

Como historiador vindo de baixo e que faz história vista de baixo, é muito gratificante revelar as lutas de certos artífices e operários que tiveram suas experiências silenciadas por rigidez teórica ou engessadas por explicações sociologizantes. O desdobramento extensionista dessas pesquisas se iniciou quando me tomei docente da FEUFF, em maio de 2012. Além de estudar os trabalhadores do passado, encontrei oportunidade para estudar com os do presente. Nesse sentido, mais uma vez, E. P. Thompson foi inspirador. Em Yorkshire e Warwick, o marxista inglês se envolveu em projetos que abriram as portas da universidade para a formação mais básica de trabalhadores jovens e adultos. Sabemos que esta experiência foi muito profícua para inspirá-lo nas

\footnotetext{
${ }^{16}$ Projeto de pesquisa "Operários e artífices organizados e sua luta pela jornada de 8 horas. Recife, 1890-1891". Financiado pela CAPES.
}

TrabalhoNecessário - www.uff.br/trabalhonecessario; Ano 12, № 18/2014. 


\section{Trabalhonecessário}

Issn: $1808-799 X$

ano 12, no $18-2014$

pesquisas e na escrita do clássico livro The making of the english working class. Pedagogicamente, o militante da New Left foi um professor que incentivava práticas de cooperação, era aberto para novas opiniões, tratava seus estudantes com isonomia e cuidava com zelo dos processos de ensino-aprendizagem. ${ }^{17}$

No período em que lecionou nos projetos extensionistas da universidade inglesa, as práticas político-pedagógicas de E. P. Thompson estiveram ancoradas na defesa da autonomia de seus estudantes. Contra a subalternidade imposta aos de baixo nos processos de ensino-aprendizagem, o marxista inglês criticou veementemente a histórica submissão das chamadas culturas populares aos saberes socialmente legitimados pelos homens de letras - herança elitista das concepções iluministas. Nesse sentido, ele defendia uma profunda relação dialética entre a educação formal e as experiências dos que viviam do suor do próprio rosto. Em seu entendimento, havia a urgente necessidade de se equilibrar o rigor intelectual exigido em espaços formais de saber e as múltiplas experiências das pessoas ditas comuns, que viviam fora dos muros acadêmicos. Para E. P. Thompson, esse exercício era fundamental para que as universidades engajadas com a educação de trabalhadores percebessem que, além de ensinar para eles, deveriam aprender com eles ${ }^{18}$.

No segundo semestre de 2012, incentivado por essas ideias e práticas, comecei a conversar com um pequeno grupo de trabalhadores terceirizados que labutam como faxineiros no campus do Gragoatá. Tinha por objetivo convencê-los de que, para setores progressistas, de esquerda e politicamente independentes,

17 SEARBY, Peter; RULE, John; MALCOLMSON, Robert. "Edward Thompson as a teacher: Yorkshire and Warwick". In: John Rule; Robert Malcolmson (eds.). Protest and survival: the historical experience - essays for E. P. Thompson. New York: The Merlin Press Ltd, 1993, p. 123.

18 THOMPSON. E. P. "Educação e experiência". In: Os românticos: a Inglaterra na era revolucionária. Rio de Janeiro: Civilização Brasileira, 2002, p. 11-47.

TrabalhoNecessário - www.uff.br/trabalhonecessario; Ano 12, № 18/2014. 


\section{Trabalhonecessário}

Issn: 1808 - 799X

ano $12, \mathrm{n}$ - $18-2014$

eles tinham voz própria e não eram invisíveis. ${ }^{19}$ Após sensibilizá-los com uma proposta isonômica, iniciamos alguns debates sobre seus anseios e de como poderíamos utilizar os recursos de nossa universidade pública, a UFF, para colaborar com suas demandas. Como resultado desses diálogos, fui induzido a acreditar que poderíamos construir um curso de EJA. Juntos, começamos a desenhar uma espécie de escola de ensino fundamental, que funcionaria no bloco $D$, onde está instalada a Faculdade Educação. As aulas ocorreriam logo após o término da jornada de trabalho dos faxineiros. Esses últimos não desejavam aulas muito extensas, pois queriam aproveitar suas merecidas horas livres para descansar e manter suas rotinas familiares e sociais.

$\mathrm{Na}$ medida em que amadurecíamos nosso movimento social, algumas graduandas da Faculdade de Educação se interessaram pela proposta. Do ponto de vista teórico e metodológico, a presença delas no grupo foi fundamental para qualificar e aprofundar o alcance político-pedagógico do projeto que se gestava. Entre outros assuntos, discutimos, no transcorrer de 2013, o lugar subalterno da EJA nas políticas públicas. Os governos tendem a implantá-la de forma precária e utilitarista, ou seja, apenas como um meio de treinamento da classe trabalhadora para o mercado. Ao diplomarem esse público, ainda produzem discutíveis relatórios para satisfazer algumas entidades internacionais. Tal postura acrítica e imediatista transforma a EJA em mera fábrica de certificados, sem qualquer preocupação mais consistente com a formação integral do ser humano. ${ }^{20}$ Para

\footnotetext{
${ }^{19}$ Sobre a invisibilidade dos funcionários terceirizados que são empregados em serviços gerais, em nossas universidades e repartições públicas, tem grande importância os estudos realizados pelo pesquisador COSTA, Fernando B. da. "Moisés e Nilce: retrados biográficos de dois garis. Um estudo de psicologia social a partir de observação participante e entrevista" (Tese de Doutorado, USP, 2008).

${ }^{20}$ Para saber mais sobre esse debate, consultar VENTURA, Jaqueline. "A trajetória histórica da educação de jovens e adultos trabalhadores". In: Lia Tiriba e Maria Ciavatta (orgs.). Trabalho e educação de jovens e adultos. Brasília, Líber Livro Editora; Niterói, Editora da UFF, 2011, p. 5797. OLIVEIRA, Romualdo P. de; ARAÚJO, Gilda C. de. "Qualidade do ensino: uma nova dimensão da luta pelo direito à educação". Revista Brasileira de Educação, (2005), n. 28, p. 5-24.
}

TrabalhoNecessário - www.uff.br/trabalhonecessario; Ano 12, № 18/2014. 


\section{Trabalhonecessário}

Issn: 1808 - 799X

ano 12 , no $18-2014$

nos descolarmos desse (des)caminho, criamos diálogos entre as propostas de E. P. Thompson e Paulo Freire, especialmente quando o educador pernambucano aposta no aprender junto - sempre de forma amorosa, autônoma e democrática. ${ }^{21} \mathrm{O}$ debate sobre temas geradores, proposto por Paulo Freire, também foi muito importante para nosso movimento social, que utiliza a EJA como meio de promoção de cidadania e protagonismo social. ${ }^{22}$ A maior parte dos faxineiros que estão conosco são mulheres e homens negros, pobres e que moram em bairros periféricos da Grande Niterói. Não há dúvidas de que esse dado é uma prova de que ainda vivemos em contextos de pós-abolição. Isso significa dizer que não superamos o racismo e a precariedade da cidadania dos negros - descendentes dos africanos escravizados. ${ }^{23}$ A premência da questão racial na montagem de nosso projeto de extensão exigiu que criássemos vínculos entre nossa espécie de escola de ensino fundamental e a lei 10.639, de 2003, que determina o estudo de História da África e das culturas negras. Nesse sentido, nas segundas-feiras, das 16:10h às 17:30h, planejamos rodas de conversa sobre a construção da

\footnotetext{
21 Sobre o assunto, indicamos especialmente a leitura de FREIRE, Paulo. Pedagogia da autonomia: saberes necessários à prática educativa, 45aㅡ edição. Rio de Janeiro: Paz e Terra, 2013.

${ }^{22}$ Temas geradores são construídos com grupos alfabetizados. "A tarefa do educador dialógico é, trabalhando em equipe interdisciplinar este universo temático recolhido na investigação, devolvêlo, como problema, não como dissertação, aos homens de quem recebeu". FREIRE, Paulo.

Pedagogia do oprimido, 54ª edição. Rio de Janeiro: Paz e Terra, 2013, p. 142.

${ }^{23}$ Sem dúvida, no tempo presente, a baixa escolaridade de nossos compatriotas negros é um dos mais visíveis e brutais componentes do nosso processo histórico. É inegável o forte vínculo do presente com nosso passado escravista. No Brasil Império, período que estudo, por exemplo, as leis vetavam o acesso do cativo à escola. Somente ao final da monarquia, quando o escravismo se desarticulava fortemente, a velha proibição caiu por terra. Mesmo os ex-escravos e seus descendentes livres encontravam dificuldades para conquistar educação formal, algo que também afetava o restante da população pobre. Além da irregular oferta de ensino básico, fruto de políticas governamentais excludentes, o acesso à escola pública era condicionado pelo favor, o que significa dizer que as matrículas estavam reservadas para os mais bem apadrinhados. Sem dúvida, por conta de sua cidadania de segunda ordem, a maior parte dos negros livres e libertos foi excluída das salas de aula. Entre outros, consultar MAC CORD, Marcelo. Artífices da cidadania. SCHUELER, Alessandra; GONDRA, José. Educação, poder e sociedade no Império brasileiro. São Paulo: Cortez, 2008. FONSECA, Marcus V. A educação dos negros: uma nova fase do processo de abolição da escravidão no Brasil. São Paulo: Edusf, 2002.
} 


\section{Trabalhonecessário}

Issn: 1808 - 799X

ano 12, no $18-2014$

cidadania negra com especialistas de diversas áreas. Os faxineiros têm o poder de escolha dos assuntos a serem debatidos.

Ainda no transcorrer do ano de 2013 , decidimos que, assim como as rodas de conversa, as aulas mais tradicionais também ocorreriam das 16:10h às 17:30h, sendo distribuídas entre terça-feira e sexta-feira. No bojo desse processo decisório, as graduandas que fazem parte da equipe foram divididas em quatro grupos de trabalho, para que escolhessem o material que orientaria os estudos dos faxineiros. Decidimos por um pacote disponibilizado pelo INEP, composto por quatro livros: matemática, ciências, história/geografia e língua portuguesa. ${ }^{24} \mathrm{Em}$ nosso entendimento, além de adequado do ponto de vista didático e políticopedagógico, esse material facilitava a organização de nossa grade de horários. Optamos pela aula de matemática nas terças. Ciências na quarta. História/Geografia, quinta. Na sexta, Língua Portuguesa. Com essa metodologia, concluiremos nossa EJA em 18 meses, mas sem abrir mão da qualidade e do compromisso com a formação - nem de forma muito acelerada, nem de forma excessivamente lenta.

\section{Considerações finais}

O nosso projeto de extensão somente foi escrito depois de finalizada toda uma longa e democrática jornada. Batizado "Limpeza Total: UFF, EJA e Trabalhadores Terceirizados", o mesmo foi aprovado pela FEUFF no início de 2014, quando lecionávamos para os faxineiros. Nosso atual desafio tem sido criar meios para que eles superem sua estima baixa, fruto de uma vida marcada por

\footnotetext{
24 Os livros são públicos, gratuitos e estão em formado PDF. Disponível em $<$ http://portal.inep.gov.br/web/encceja/livro-do-estudante-ensino-fundamental>. Acesso em 23/3/2014.
}

TrabalhoNecessário - www.uff.br/trabalhonecessario; Ano 12, № 18/2014. 


\section{Trabalhonecessário}

Issn: 1808 - 799X

ano 12 , no $18-2014$

subalternidade sócio-profissional, racismo, sexismo e experiências autoritárias de escolarização. Todas essas terríveis facetas da exclusão jogam sobre suas costas "culpas" que não lhes pertencem. Acredito que superaremos essa fase, pois uma das virtudes de nosso movimento social é seu espírito fraterno, coletivista e igualitário. Todos nos sentimos protagonistas da iniciativa, o que gera uma crescente sensação de capacidade. Assim como E. P. Thompson afirmou que a classe operária não surgiu como o sol, pois foi forjada em um longo processo de luta, temos a esperança de que também possamos nos reconstruir e nos reinventar em nossa pequena (mas significativa) iniciativa extensionista.

O legado historiográfico de E. P. Thompson é fundamental para valorizarmos as experiências dos trabalhadores do passado. A história vista de baixo legitima as expectativas dos sujeitos que viveram em outras épocas, permitindo que os deixemos falar por meio das fontes disponíveis. Aprendemos a compreendê-los considerando seus valores, sem julgá-los aprioristicamente como típicos ou atípicos, de acordo com nossos dogmas teóricos. Entretanto, não menos importantes foram as vivências do marxista inglês enquanto docente envolvido com as classes subalternas. Com os de baixo, ele exercitou uma boa interlocução por meio de democráticos processos político-pedagógicos - o que permitiu que trocasse conhecimentos com os trabalhadores de seu tempo. No diálogo entre passado e presente, entre militância e rigor científico, E. P. Thompson deixou para todos nós uma vigorosa práxis. E que ela sirva de inspiração para todos os homens e mulheres de esquerda que são social e intelectualmente solidários aos mais pobres. 


\section{Trabalhonecessário}

Issn: $1808-799 X$

ano 12, no $18-2014$

\section{Referências bibliográficas.}

BATALHA, Claudio H. M. "A historiografia da classe operária no Brasil: trajetórias e tendências". In: Marcos C. de Freitas (org.). Historiografia brasileira em perspectiva. São Paulo: Contexto, 2003, p. 145-58.

"Identidade da classe operária no Brasil (1880-1920): atipicidade ou legitimidade?". Revista Brasileira de História, (set. 1991/ago. 1992), v. 12, n. 23/24, p. 111-24.

CARVALHO, José M. de. Cidadania no Brasil: o longo caminho, 13르 ed. Rio de Janeiro: Civilização Brasileira, 2010.

CHALHOUB, Sidney. Visões da liberdade: uma história das últimas décadas da escravidão na Corte. São Paulo: Companhia das Letras, 1990.

. "Visões da liberdade: uma história das últimas décadas da escravidão na Corte" (Tese de Doutorado, UNICAMP, 1989).

; TEIXEIRA, Fernando. "Sujeitos no imaginário acadêmico: escravos e trabalhadores na historiografia brasileira desde os anos 1980". Cadernos AEL, (2009), v. 14, p. 11-50.

; FONTES, Paulo. "História Social do Trabalho, História Pública". Perseu: história, memória e política, (2009), n. 4, ano 3, p. 219-28.

COSTA, Fernando B. da. "Moisés e Nilce: retrados biográficos de dois garis. Um estudo de psicologia social a partir de observação participante e entrevista" (Tese de Doutorado, USP, 2008).

FONSECA, Marcus V. A educação dos negros: uma nova fase do processo de abolição da escravidão no Brasil. São Paulo: Edusf, 2002.

FORTES, Alexandre. Nós do Quarto Distrito: a classe trabalhadora Portoalegrense e a Era Vargas. Rio de Janeiro: Editora Garamond, 2004.

Vargas" (Tese de Doutorado, UNICAMP, 2001).

FREIRE, Paulo. Pedagogia da autonomia: saberes necessários à prática educativa, 45aㅡ edição. Rio de Janeiro: Paz e Terra, 2013.

. Pedagogia do oprimido, 54a edição. Rio de Janeiro: Paz e Terra, 2013.

GOMES, Flávio dos S. Histórias de quilombolas: mocambos e comunidades de senzalas - Rio de Janeiro, século XIX. Rio de Janeiro: Arquivo Nacional, 1993.

TrabalhoNecessário - www.uff.br/trabalhonecessario; Ano 12, № 18/2014. 


\section{Trabalhonecessário}

Issn: 1808 - 799X

ano 12, no $18-2014$

. "Histórias de quilombolas: mocambos e comunidades de senzalas - Rio de Janeiro, século XIX" (Dissertação de Mestrado, UNICAMP, 1993).

GORENDER, Jacob. A escravidão reabilitada. São Paulo: Editora Ática, 1990.

GUIMARÃES, Reinaldo da S. Afrocidanização: ações afirmativas e trajetórias de vida no Rio de Janeiro. Rio de Janeiro, Editora da PUC-RJ; São Paulo, Selo Negro Edições, 2013.

LARA, Silvia H. "Escravidão, cidadania e história do trabalho no Brasil". Projeto História, (1998), n. 16, p. 25-38.

"Blowin'in the wind: E. P. Thompson e a experiência negra no Brasil".

Projeto História, (1995), n. 12, 1995, p. 43-56.

Campos da violência: estudo sobre a relação senhor-escravo na capitania do Rio de Janeiro, 1750-1808. São Paulo: Paz e Terra, 1988.

. "Campos da violência: estudo sobre a relação senhor-escravo na capitania do Rio de Janeiro, 1750-1808" (Tese de Doutorado, USP, 1986).

MAC CORD, Marcelo. Artífices da cidadania: mutualismo, educação e trabalho no Recife oitocentista. São Paulo: Editora da UNICAMP, em 2012.

"Andaimes, casacas, tijolos e livros: uma associação de artífices no

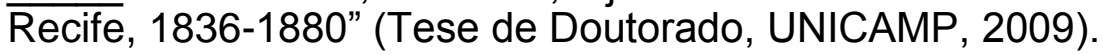

NEGRO, Antonio L.; GOMES, Flávio dos S. "Além de senzalas e fábricas: uma história social do trabalho". Tempo Social: revista de sociologia da USP, (2006), v. 18, n. 1, p. 217-40.

OLIVEIRA, Romualdo P. de; ARAÚJO, Gilda C. "Qualidade do ensino: uma nova dimensão da luta pelo direito à educação". Revista Brasileira de Educação, (2005), n. 28, p. 5-24.

SCHUELER, Alessandra; GONDRA, José. Educação, poder e sociedade no Império brasileiro. São Paulo: Cortez, 2008.

SEARBY, Peter; RULE, John; MALCOLMSON, Robert. "Edward Thompson as a teacher: Yorkshire and Warwick". In: John Rule; Robert Malcolmson (eds.).

Protest and survival: the historical experience - essays for E. P. Thompson. New York: The Merlin Press Ltd, 1993, p. 1-23.

SHARPE, Jim. "A história vista de baixo". In: Peter Burke (org.). A Escrita da história: novas perspectivas. São Paulo: Editora da UNESP, 1992, p. 39-62.

THOMPSON. E. P. "Educação e experiência”. In: Os românticos: a Inglaterra na era revolucionária. Rio de Janeiro: Civilização Brasileira, 2002, p. 11-47.

TrabalhoNecessário - www.uff.br/trabalhonecessario; Ano 12, № 18/2014. 


\section{Trabalhonecessário}

Issn: $1808-799 X$

ano 12, no $18-2014$

A formação da classe operária inglesa: a árvore da liberdade, v. 1, $3^{\text {a }}$ ed. Rio de Janeiro: Paz e Terra, 1997.

VENTURA, Jaqueline. "A trajetória histórica da educação de jovens e adultos trabalhadores". In: Lia Tiriba e Maria Ciavatta (orgs.). Trabalho e educação de jovens e adultos. Brasília, Líber Livro Editora; Niterói, Editora da UFF, 2011, p. 57-97.

Recebido em maio de 2014

Aprovado em junho de 2014

TrabalhoNecessário - www.uff.br/trabalhonecessario; Ano 12, № 18/2014. 